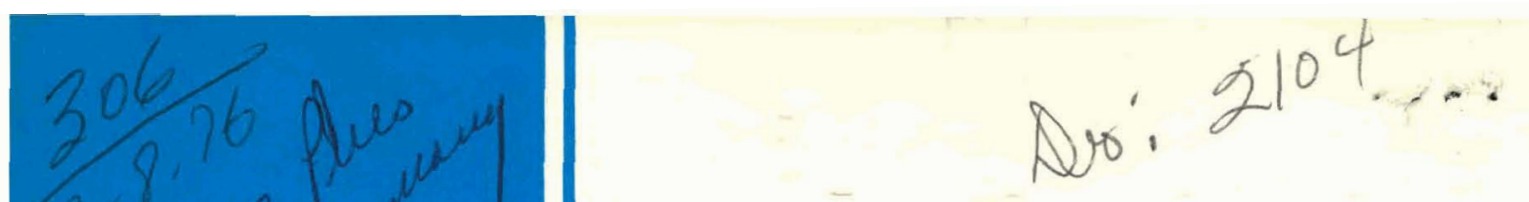

\title{
Fission Product Beta and Gamma Energy Release Quarterly Progress Report for October-December 1975
}

\author{
J. K. Dickens \\ T. A. Love \\ J. W. McConnell \\ J. F. Emery \\ R. W. Peelle
}




\section{DISCLAIMER}

This report was prepared as an account of work sponsored by an agency of the United States Government. Neither the United States Government nor any agency Thereof, nor any of their employees, makes any warranty, express or implied, or assumes any legal liability or responsibility for the accuracy, completeness, or usefulness of any information, apparatus, product, or process disclosed, or represents that its use would not infringe privately owned rights. Reference herein to any specific commercial product, process, or service by trade name, trademark, manufacturer, or otherwise does not necessarily constitute or imply its endorsement, recommendation, or favoring by the United States Government or any agency thereof. The views and opinions of authors expressed herein do not necessarily state or reflect those of the United States Government or any agency thereof. 


\section{DISCLAIMER}

Portions of this document may be illegible in electronic image products. Images are produced from the best available original document. 
Printed in the United States of America. Available from

Naliural Teclurical Iıfun unaliun Gervice

U.S. Department of Commerce

5285 Port Royal Road, Springfield, Virginia 22161

Price: Printed Copy \$4.50; Microfiche $\$ 2.25$

This report was prepared as an account of work sponsored by the United States Government. Neither the United States nor the Energy Research and Development Administration, nor any of their employees, nor any of their contractors, subcontractors, or their employees, makes any warranty, express or implied, or assumes any legal liability or responsibility for the accuracy, completeness or usefulness of any information, apparatus, product or process disclosed, or represents that its use would not infringe privately owned rights. 
Contract No. W-7405-eng-26

Neutron Physics Division

FISSION PRODUCT BETA AND GAMMA ENERGY RELEASE

QUARTERLY PROGRESS REPORT FOR OCTOBER-DECEMBER 1975

J. K. Dickens, T. A. Love, J. W. McConnell

J. F. Emery*, and R. W. Peelle

FEBRUARY 1976.

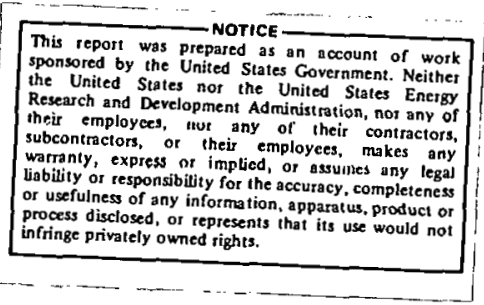

*Analytical Chemistry Division

NOTICE This dooumont oontoine information of a proliminary nasure and was prepared primarily for internal use at the Oak Ridge National Laboratory. It is subject to revision or correction and therefore does not represent o final report.

Work performed by Union Carbide Corporation for the U. S. Nuclear Regulatory Commission under Interagency Agreements 40-551-75 and 40-552-75.

OAK RIDGE NATIONAL LABORATORY

Oak Ridge, Tennessee 37830

operated by

UNION CARBIDE CORPORATION

for the

ENERGY RESEARCH AND DEVELOPMENT ADMINISTRATION 
Abstract

Preliminary experimental information for beta-ray energy release from fission product decay following thermal-neutron fission of ${ }^{235} \mathrm{U}$ has been obtained for cooling times between 3 and 14,400 secs. The data were obtained as pulse-height spectra for beta energies between 0.25 and $8 \mathrm{MeV}$ using a two-crystal scintillation spectrometer, and were unfolded to give beta-ray energy spectra of moderate resolution. Two irradiation times, $t_{i}=2.4$ and $100 \mathrm{sec}$, were studied. The energy release data were obtained by integrating the observed spectra and then estimating the contribution for $E_{\beta}<0.25 \mathrm{MeV}$. Difficulties encountered in this first experiment using the beta-ray detection equipment are discussed.

Previously reported preliminary gamma-ray spectra have been compared with spectra calculated using spectral information in the ENDF/B-IV data file for $\sim 180$ fission products. Several comparisons are presented for $t_{i}=100$ secs. As expected the comparison is not very good for short cooling times, but is encouraging for $t_{\operatorname{cool}} \sim 2000$ secs. 


\section{INTRODUCTION}

The purpose of this experiment is to measure the total beta and gamma energy release rate from fission product decay following thermal neutron fission of fuel materials ${ }^{235} \mathrm{U}$ and then ${ }^{239} \mathrm{Pu}$ and perhaps other nuclides. The accuracy goal is $\pm 3 \%$ on the overa11. energy release rate for ${ }^{235} \mathrm{U}$ and $\pm 4 \%$ for ${ }^{239} \mathrm{Pu}$ for times following fission of 2 to at least $2000 \mathrm{sec}$. The experimental methods wese outlined in the first quarterly report, 1 and details of the detector systems, fission-monitoring, samples and sample transport, and data accumulation computer have been reported in subsequent quarterly reports. ${ }^{2}$ Preliminary measurements and results for gamma-ray energy release data were reported in the last quarterly report. ${ }^{3}$

\section{EXPERIMENTAL PROGRESS}

During the quarter emphasis was placed on obtaining, reducing and reporting preliminary beta-ray energy release data for a "quick look" comparisnn with other data ${ }^{4}, 5$ as well as calculations. In addition, il was anticipated that this first pass through the whole experiment for the beta-ray data would provlde answers to questions ahnut methods and procedures which had not previously been attempted, and wuuld serve to emphasize those methods and procedures requiring improvement prior to the final data accumulation runs.

To date a satisfactory sample holder has not been fabricated for the beta-ray measuremerits. The sample configuration ought to approach one made by seallng the ${ }^{235} \mathrm{U}$ between two sheets of plastic material, each sheet being just thick enough to contain the most energetic fission fragments. This sample holder ought to be mounted near to the end of 
the "rabbit" (used to transport the sample to and from the reactor) so as to minimize the air path between sample and detector. This problem of source holder has proved to be very stubborn. For the first data run, the sample holders were a rather thick $55 \mathrm{mg} / \mathrm{cm}^{2}$, about ten times thicker than needed. As a consequence data could not be obtained for $E_{\beta}<0.25$ $\mathrm{MeV}$.

The beta-ray detector as used in the preliminary measurements is shown in Fig 1. The two-scintillator system is designed to identify and reject part of the gamma radiation detected, and also to provide an active shield against general room background. Magnetic separation of betas from gammas is accomplished by using a strong magnetic field applied between the first collimator and the source position. The measurements consisted of two types: (a) without the magnetic field, the detector system records essentially all incident betas and some fraction, $f$, of the incident gammas, since $(1-f)$ of the incident gamma radiation is identified and rejected by the electronic pulse-shape discrimination; (b) with the magnetic field, the detector system records only the fraction, $f$, of the incident gamma radiation. Data reduction includes subtracting data runs of type (b) from those of type (a). The resulting spectrum is, therefore, expected to be due to betas only. It is binned into suitable pulse-height bins and then unfolded. Prior to this step, however, a response matrix had to be determined for the detector configuration used.

A beta-ray response matrix was calculated based upon the assumptions that every beta ray striking the detector is registered, that the attenuation of betas through scattering by the source hn1 Her - air - entrance 


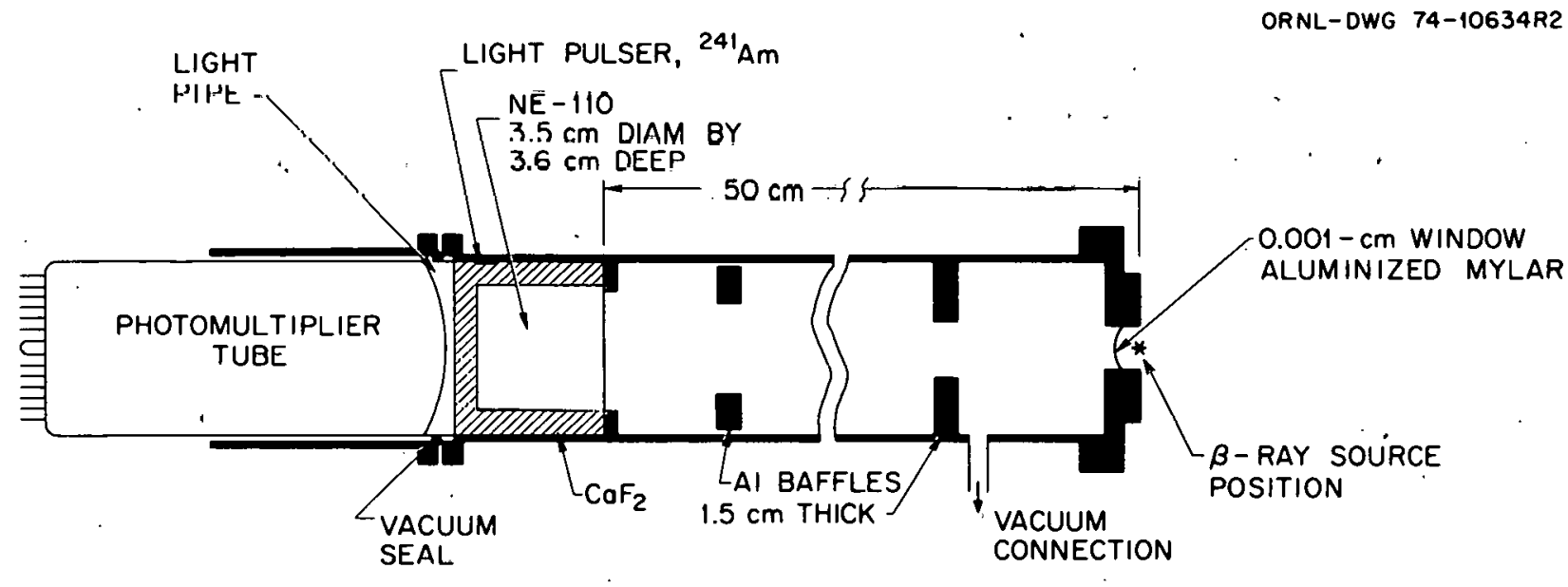

Fig 1. Beta-ray scintillation spectrometer as used for preliminary beta-ray energy release measurements. 'l'he beta-ray surce pusition is about $8 \mathrm{~mm}$ from the entrance foil. For some measurements a strong magnetic field ( $\sim 2700$ gauss) is placed between the entrance foil and the first collimator perpendicular to the path between source and detector. The "Light Pulser, ${ }^{241} \mathrm{Am}$ " is used to monitor possible gain shifts during data taking. 
window can be calculated, and that energy loss can also be calculated. For $E_{\beta}<1 \mathrm{MeV}$ conversion electron sources provided information on the intrinsic resolution of the detector as well as information on the departure of the response from pure Gaussian. For $\mathrm{E}_{\beta}>1 \mathrm{MeV}$ these effects were extrapolated to calculate responses.

Beta-ray energy-release data for thermal-neutron fission of ${ }^{235} \mathrm{U}$ were obtained during the quarter and were processed using this response matrix. In addition, data were obtained for a ${ }^{207} \mathrm{Bi}$ conversion electron source. After unfolding, the results were within $3 \%$ for the $484-\mathrm{keV}$ and 975-keV conversion-electron yields calculated from the known ${ }^{207} \mathrm{Bi}$ source strength and conversion electron branching ratios. Data were also obtained for an aluminum sample; the betas measured were the $2.86-\mathrm{MeV}$ beta rays from ${ }^{28} \mathrm{Al}$. These data are shown in Fig 2. The dashed curve represents the expected spectrum. The comparison for $E_{B}>1 \mathrm{MeV}$ is quite good, but for $E_{B}<0.8 \mathrm{MeV}$, the differences are large enough to be of concern. Further study is required prior to final data taking. For thermal-neutron fission of ${ }^{235} \mathrm{U}$ beta-ray data were obtained for irradiation times of 2.4 and 100 secs, and for counting time intervals the same as were used for the gamma-ray data reported last quarter. ${ }^{3}$ The unfolded beta-ray energy spectra were compared with data of Tsoulfanidis, et al.; ${ }^{4}$ a typical comparison is shown in Fig 3 . The causes for observed differences have not yet been investigated.

The thick absorbing layer, $55 \mathrm{mg} / \mathrm{cm}^{2}$ of plastic between the sample and the detector, required that the lowest energy portion of the spectrum be extrapolated in order to obtain the integral heat-release data. These estimates ranged between $1 \%$ for shortest cooling times to $12 \%$ for longest 


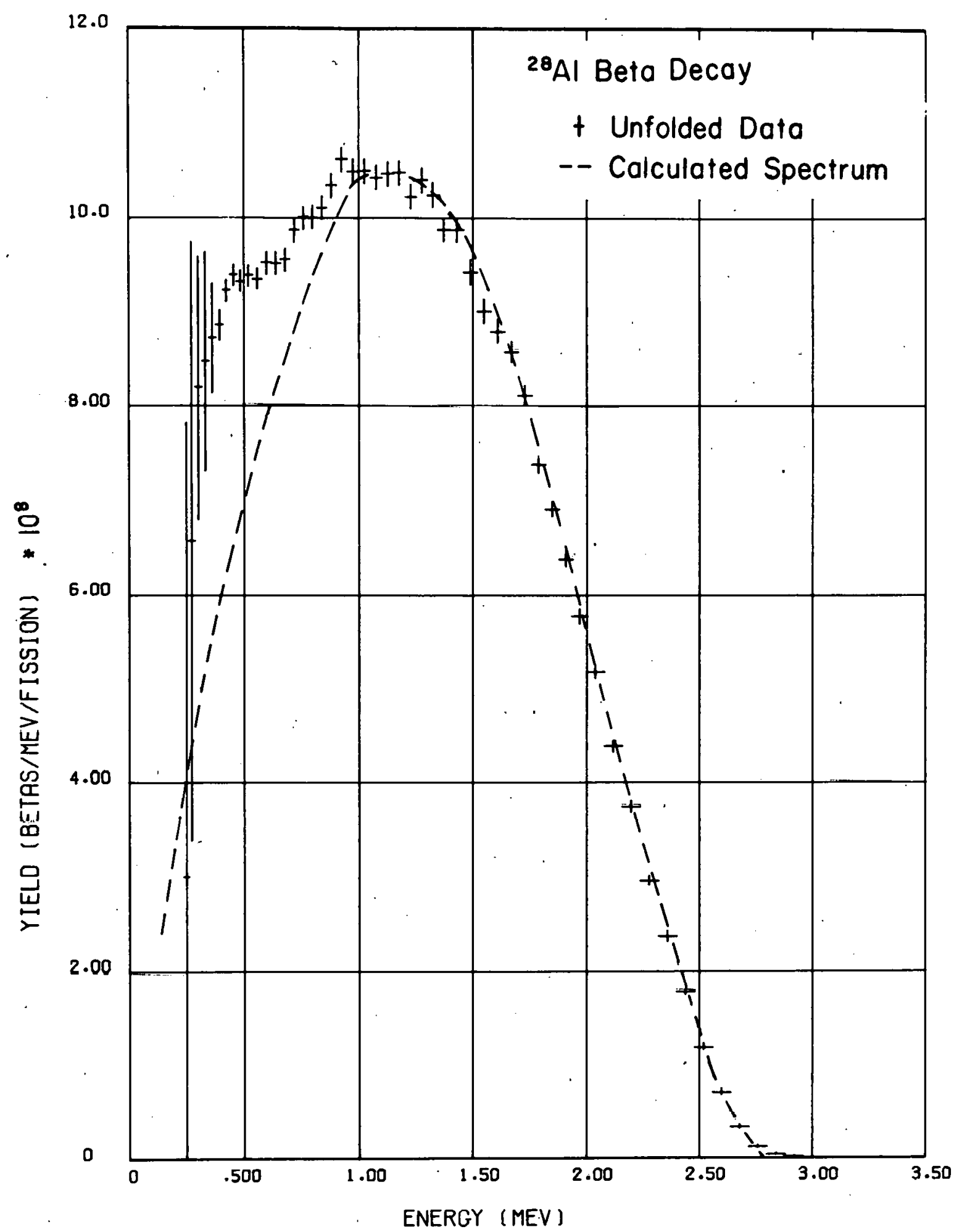

Fig 2. Spectrum of betas obtained by bombarding a $1.7 \mathrm{mg}$ sample of $\mathrm{Al}$ for $10 \mathrm{sec}$ in a thermal flux of $3.6 \times 10^{13} \mathrm{n} / \mathrm{cm}^{2} / \mathrm{sec}$, and unfolding the raw data using the response matrix discussed in the text. The dashed line is calculated assuming an allowed transition, that is, a straight line would result when the data are manipulated to give a Fermi plot. 


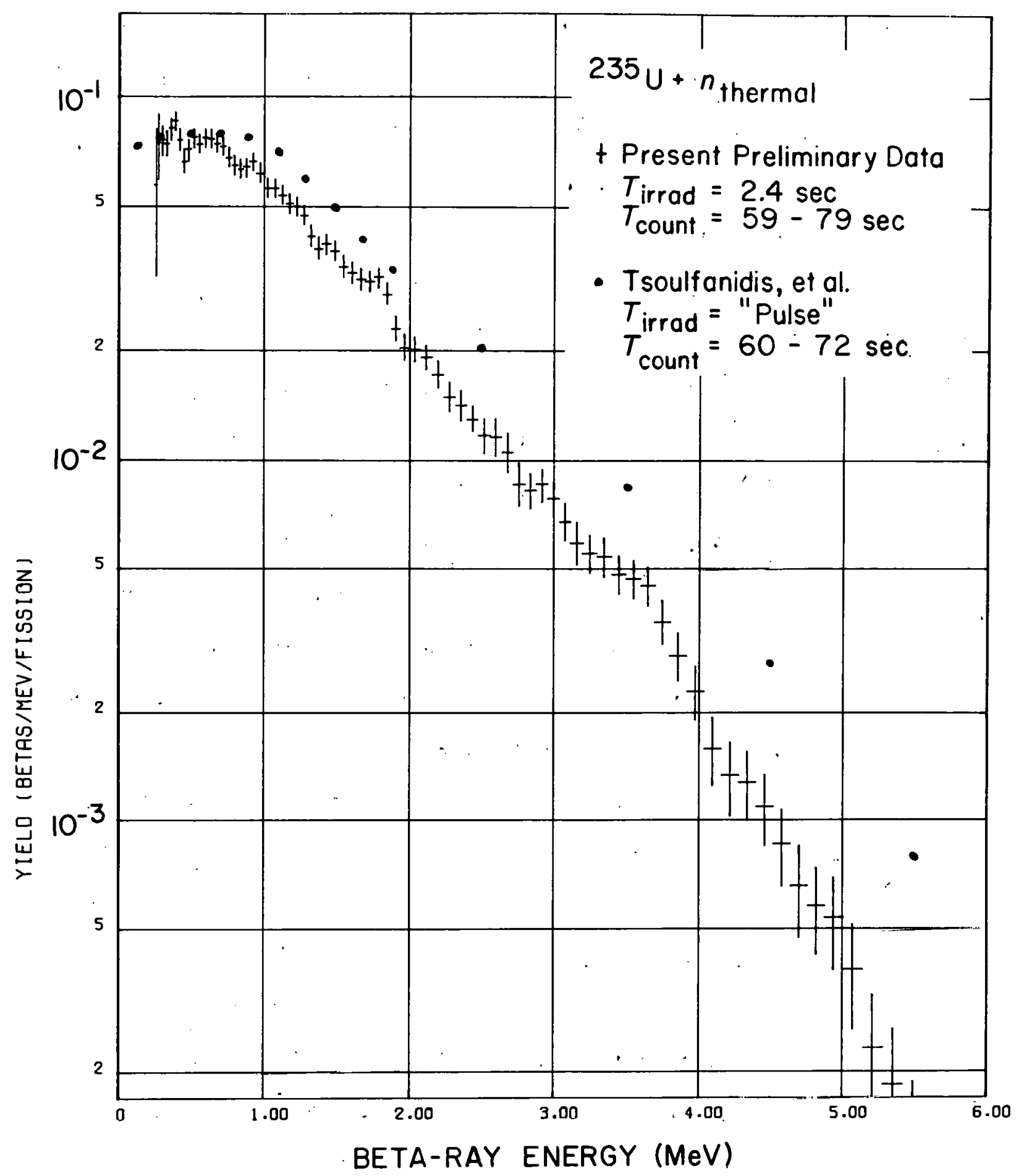

Fig 3. Comparison of present preliminary beta-ray data with those of Tsoulfanidis, et a1. (Ref 4) for cooling times of 60 to 70 secs. 
cooling times. An example of the latter is shown in Fig 4; the estimate is shown as the dashed line and is probably an overestimate since $E_{\beta} \times Y_{B}$ should be identically zero for zero energy.

Of concern was the apparent lack of precision for data obtained under presumed identical conditions. Integral values of some of the experimental data (e.g. number of pulses presented to the Analog-toDigital Convertor, etc.) were oblained during each run using scalers. During the, data reduction, a study was made to obtain the degree of reproducibility of these integral values, since this is one measure of the internal consistency of the data. The results of this study are given in Table 1, along with equivalent results for the preliminary gamma-ray energy-release data. Becausc of the inrnnsistencies for the beta-ray data, the final experimental values are shown with uncertainties of $11 \%$ or greater. For this reason, as well as the expectation of substantial improvement in methods and techniques (e.g. in sample cover thickness) which may be anticipated for data accumulation runs being planned, use of these beta-ray data should be restricted to unpublished studies.

The resulting preliminary beta-ray energy release data are included in Table 2, along w1th preliminary gamma-xay energy release data ${ }^{3}$ and calculated energy release data using the ENDF/B-IV data file. ${ }^{6}$ For these calculations the function $f(t)=$ energy release/flssion/sec aflui a cooling time $t$, for an instantaneuus burst of fission was obtained separately for beta-ray and gamma-ray energy release by R. Schenter ${ }^{7}$ (Hanford) using the RIBD code. Each $f(t)$ was numerically integrated over the irradiation time to create $F\left(t, t_{\text {irrad }}\right)$, where the notation is 


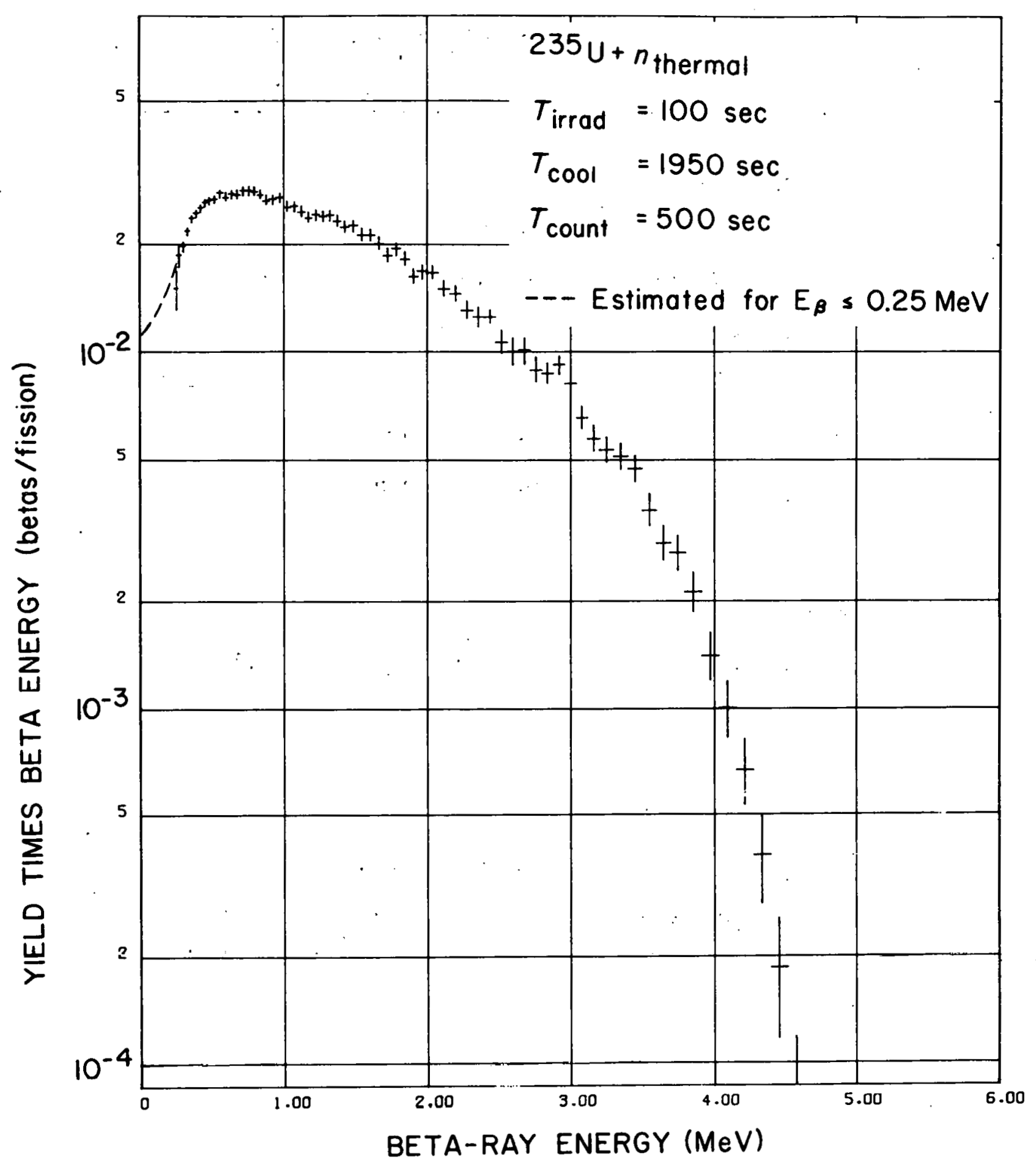

Fig 4. Present preliminary beta-ray data plotted as Yield $x$ Energy vs. Energy to show the extrapolation at low $E_{\beta}$ in order to obtain the integral heat. For shorter cooling times the estihated heat for $\mathrm{E}_{B}<0.25 \mathrm{MeV}$ is a smaller percentage of the total integral than shown here. In addition, Yield $x$ Energy $\rightarrow 0$ for Zero Energy which is not indicated here; hence the estimate may be conservalive. 
TABLE 1. INTERNAL CONSISTENCY OF PRELIMINARY DATA (Representative Values for $1 \sigma$ Variations)

A. Gamma-Ray Data
1) $T_{i}=2.4 \mathrm{sec}$
Low gain
$3.8 \%$
2) $T_{i}=100 \mathrm{sec}$
Low gain
$1.0 \%$
3) $\mathrm{T}_{1}=2.4 \mathrm{ser}$
High gain
$4.2 \%$
4) $T_{4}=100 \mathrm{gec}$
High gàin
One Samp le
5) $T_{1}=2.4 \mathrm{sec}$
No. of fissions
$4.5 \%$
6) $T_{i}=100 \mathrm{sec}$
No. of fissions
$1.7 \%$

B. Beta-Ray Data
1) $T_{i}=2.4 \mathrm{sec}$
Low gain
$8.3 \%$
2) $\mathrm{T}_{i}=100 \mathrm{sec}$
Low gain
One Sample
3) $T_{i}=2.4 \mathrm{sec}$
High gain
$11.3 \%$
4) $\bar{T}_{i}=100 \mathrm{sec}$
Iligh gain
$9.0 \%$
5) $\mathrm{T}_{i}=2.4 \mathrm{sec}$
No. of fissions
$3.7 \%$
6) $T_{i}=100 \mathrm{sec}$
No. of fissions
$1.9 \%$ 
Table 2. PRELTMINARY ENERGY RELEASE DATA AND COMPARISONS

(December 1975)

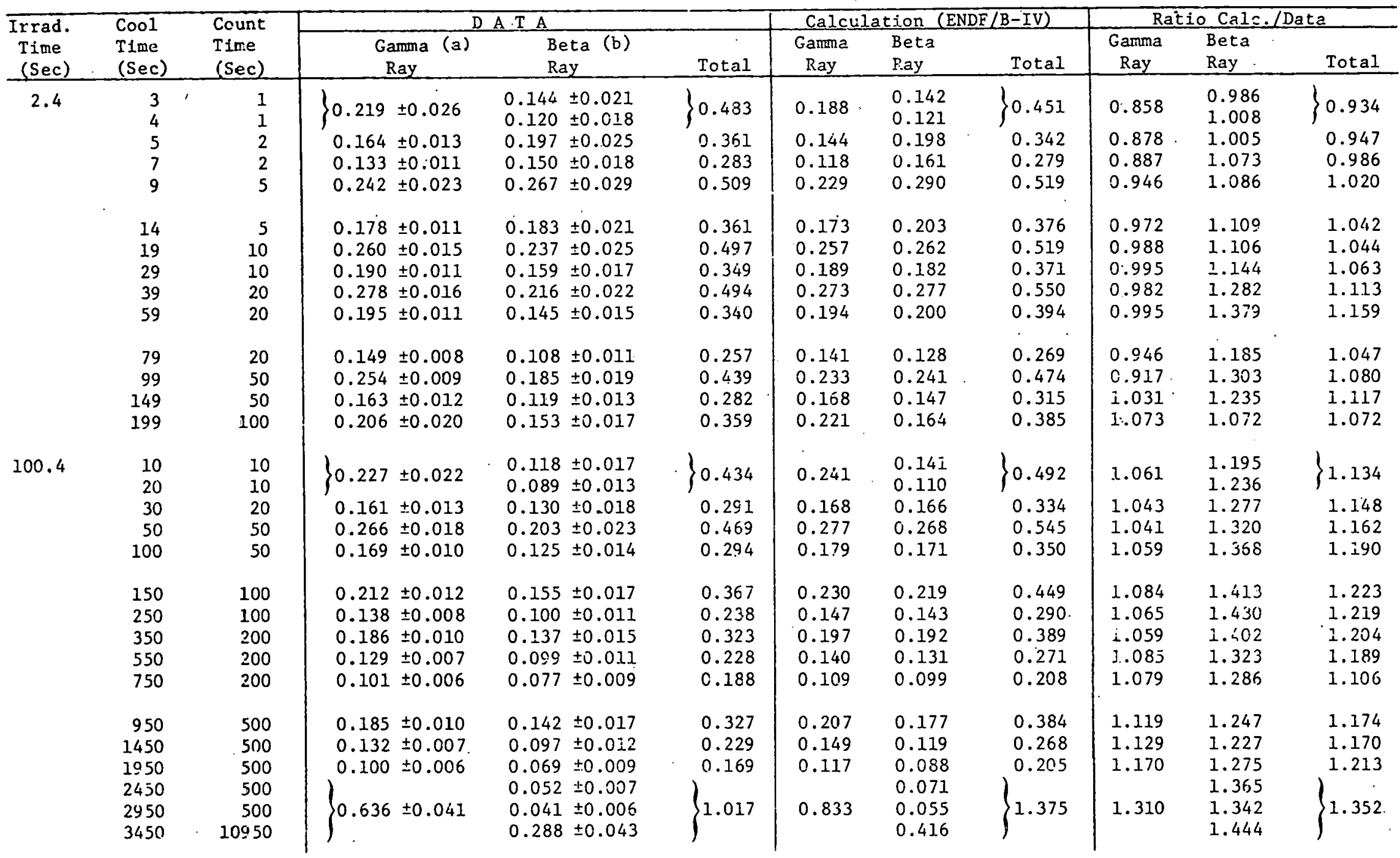

(a) For $E_{Y}>0.05 \mathrm{MeV}$

(b) Includes estinates for $\mathrm{E}_{\beta}<0.25 \mathrm{MeV}$ 
taken from the recent Perry, et al. ${ }^{B}$ report: $F(t, T)=$ energy release/ fission after a cooling time $t$ for an irradiation at constant power for a period $T$. Then $F(t, T)$ was numerically integrated over each counting time interval to get the expected yields, and these are shown in Table 2 as "Calculation." The last three columns of Table 2 give the ratios of calculated values to data. The ratios are larger than anticipated. The beta-ray data-taking system 1 s beling suljected to a thorough analysis; in particular, efforts continue to tabricate sample hulders with thin plastic foils which can withstand the mechanical shocks incurred during movement to and from the reactor.

\section{COMPARISONS OF GAMMA-RAY SPECTKA WITH CALCULATED SPECTRA}

During the quarter calculations using the ORIGEN code and those isotopes in the ENDF/B-IV data file having discrete spectral information were carried out to compute the gamma-ray spectrum expected for a given irradiation and counting time. The calculated results were compared with the data ${ }^{3}$ obtained for $t_{\text {irrad }}=100$ secs. Two of these comparisons are shown in Figs 5 and 6 . Only $\sim 180$ of the $>500$ fission products have spectral information given in ENDF/B-IV. Even with the "poor" resolution associated with the NaI system, these comparisons should be of material benefit as a guide to improving the ENDF/B data file.

\section{ACKNOWLEDGMENT}

We wish to express our appreciation to H. Weaver, J. Northcutt, E. Plemons, G. Morrison, C. Miller, R. Abele, R. Freestone, V. Emert, N. Case, C. McFarland, C. Murin, and R. Seals for their assistance on this project during the quarter. 


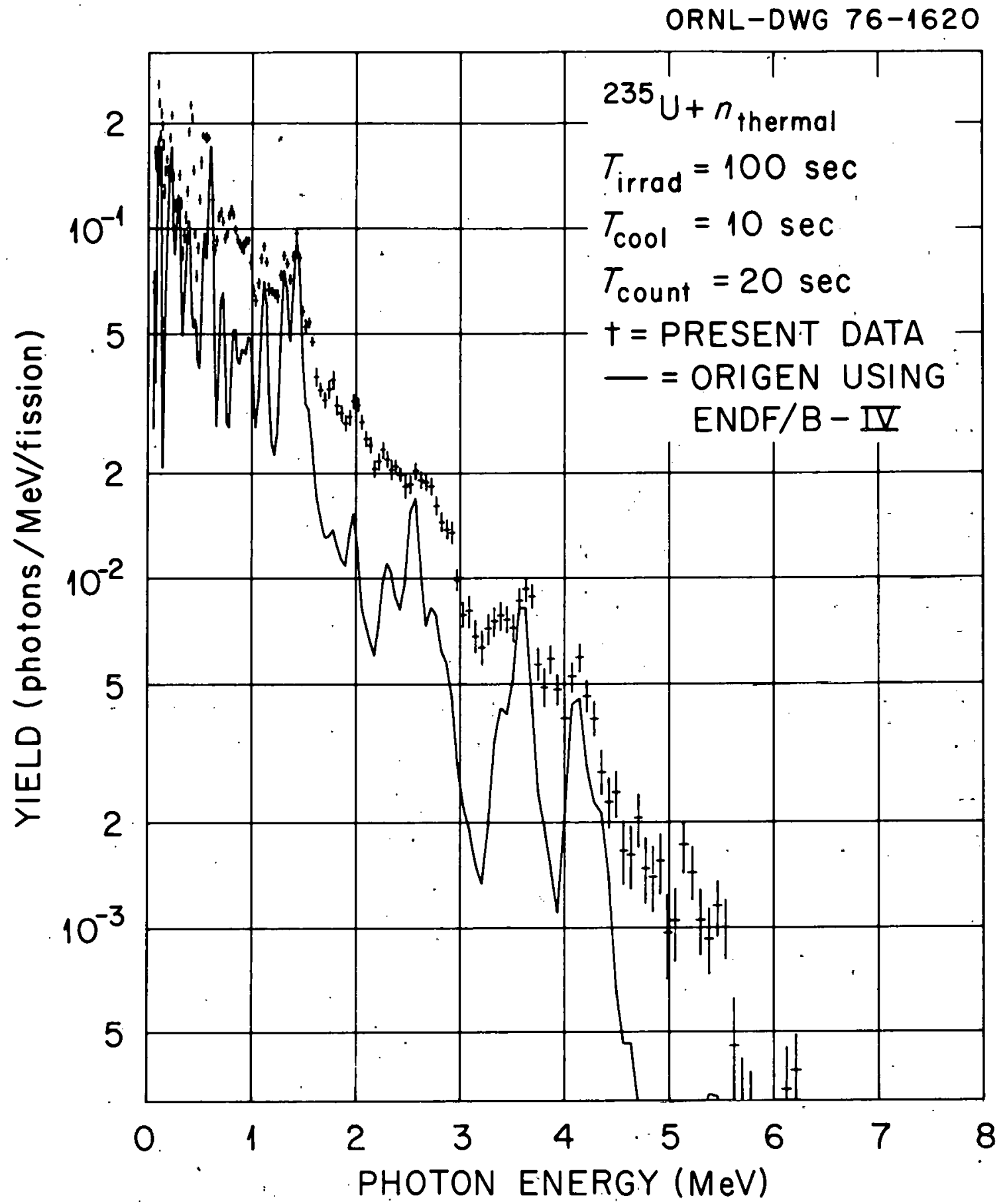

F1g 5. Comparison of present preliminary gamma-ray data, with calculations using ORIGEN and spectral information for fission products in the ENDF/B-IV data file. Parameters of the measurement are given on the figure. 


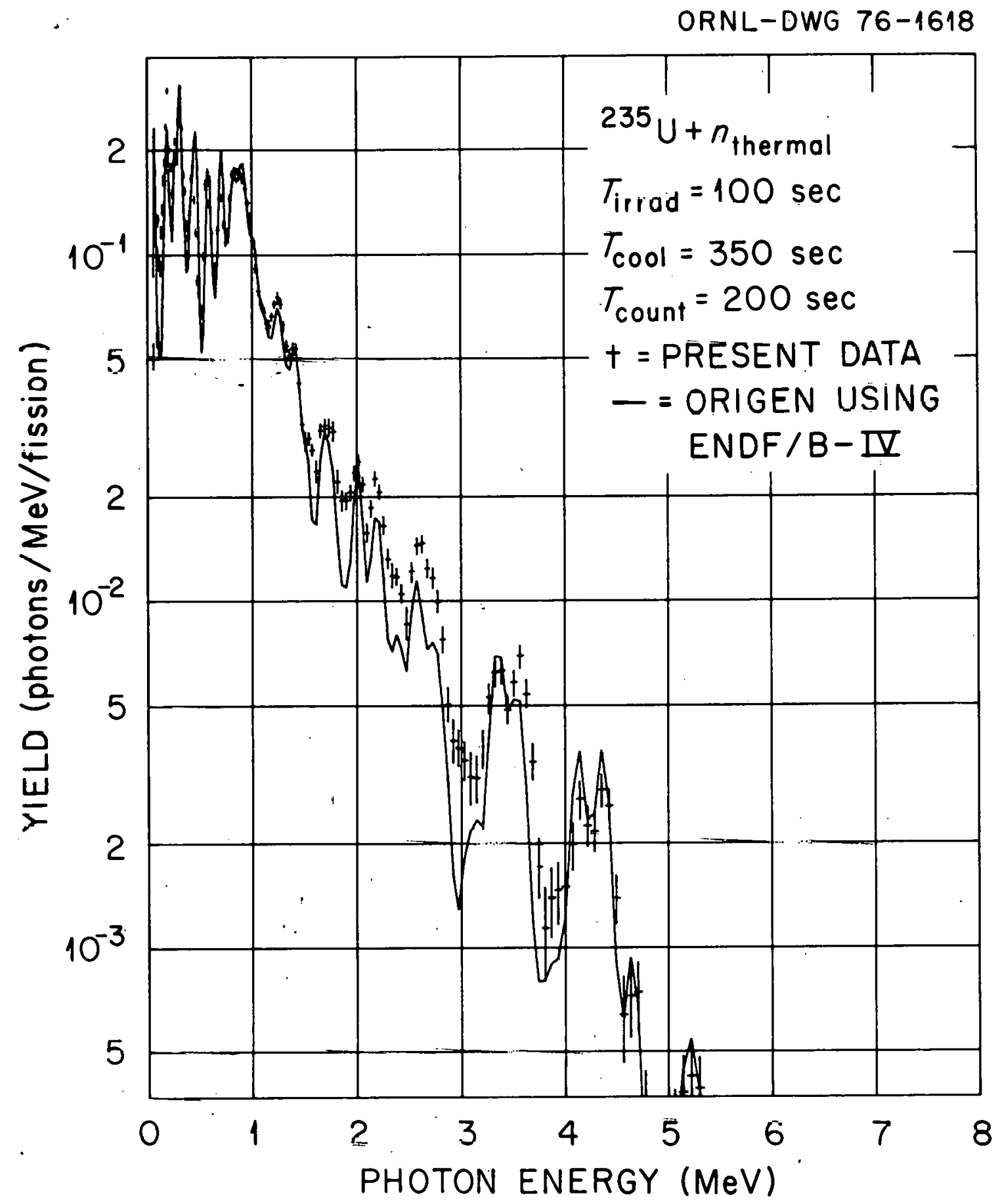

Fig 6. Comparison of present preliminary gamma-ray data with calculations using ORIGEN and spectral information for fission products in the ENDF/B-IV data file. Parameters of the measurement are given on the figure. 


\section{REFERENCES}

1. Quarterly Progress Report on Reactor Safety Programs Sponsored by the Division on Reactor Safety Research for April-June 1974, ORNL-TM-4655, vo1. I, Pp 33-41.

2. Quarterly Progress Report on Reactor Safety Programs Sponsored by the Division of Reactor Safety Research for July-September 1974, ORNL-TM-4729, vol. I, Pp. 54-57.

Quarterly Progress Report on Reactor Safety Programs Sponsored by the NRC Division of Reactor Safety Research for OctoberDecember 1974, ORNL-TM-4805, vol. I, pp. 81-83.

Quarterly Progress Report on Reactor Safety Programs Sponsored by the NRC Division of Reactor Safety Research for January-March 1975, ORNL-TM-4914, vol. I, pp. 55-56.

Quarterly Progress Report on Reactor Safety Programs Sponsored by the NRC Division of Reactor Safety Research for April-June 1975, ORNL-TM-5021, vol. I, pp. 62-64.

3. J. K. Dickens, T. A. Love, J. W. McConnell, J. F. Emery, and R. W. Peelle, "Fission Product Beta and Gamma Energy Release Quarterly Progress Report for July-September 1975," ORNL-TM-5156.

4. N. Tsoulfanidis, B. W. Wehring, and M. E. Wyman, Nucl. Sci. Eng. $\underline{43}, 42$ (1971).

5. J. W. Kutcher and M. E. Wyman, Nucl. Sci. Eng. 26, 435 (1966).

6. T. R. England and R. E. Schenter, "ENDF/B-IV Fission Product Files: Summary of Major Nuclide Data," LA-6116-MS (1975).

7. R. E. Schenter (private communication, November 1975).

8. A. M. Perry, F. C. Maienschein, and D. R. Vondy, "Fisston Product Afterhead - A Review of Experiments Pertinent to the Therma1-Neutron Fisșion of ${ }^{235} \mathrm{U}, "$ ORNL-TM-4197 (Octoher 1.973). 
THIS PAGE

\section{WAS INTENTIONALLY LEFT BLANK}


ORNL/TM-5272

NRC -1 and -3

INTERNAL DISTRIBUTION

1. L. S. Abbott
2. J. V. Cathcart
3. R. H. Chapman
4. W. B. Cottrell
5. F. L. Culler
6. J. K. Dickens
7. J. F. Emery
8. G. G. Fee
9. D. O. Hobson
10. T. A. Love
11. W. S. Lyon
12. F. C. Maienschein
13. A. P. Malinauskas
14. J. W. McConnell
15. G. W. Morrison
16. F. R. Mynatt
36. R. W. Peel.le
37. H. Postma
38. R. W. Roussin
39. I. Spiewak

1. L. S. Abbott

2. J. V. Cathcart

3. R. H. Chapman

4. W. B. Cottrell

5. F. L. Culler

6. J. K. Dickens

7. J. F. Emery

10. T. A. Love

11. W. S. Lyon

12. F. C. Maienschein

13. A. P. Malinauskas

14. J. W. McConnell

15. G. W. Morrison

16. F. R. Mynatt

17-36. R. W. Peel.le

37. H. Postma

39. I. Spiewak
40. D. G. Thomas

41. D. B. Trauger

42. D. R. Vondy

43. J. R. Weir

44. C. R. Weisbin

45. J. C. White

46. A. Zucker

47. P. F. Fox (consultant)

48. W. W. Havens (consultant)

49. A. F. Henry (consultant)

50. R. E. Uhrig (consultant)

51. ORNL Patent office

52-53. Central Research Library

54-55. Laboratory Records Department

56. Laboratory Records (RC)

57. Nuclear Safety Information Center

58. ORNL Y-12 Technical Library Document Reference Section

\section{EXTERNAL DISTRIBUTION}

59-66. Director, Division of Reactor Safety Research, NRC, Washington D. C. 20555.

67. Director, Reactor Division, ERDA-ORO.

68. Director, Research and Technical Support Division, ERDA-ORO.

69-71. Los Alamos Scientific Laboratory, P. 0. Box 1663, Los Alamos, New Mexico 87544. Attention: T. R. England, Roger Perkins, and John Yarnell.

72-73. Department of Nuclear Engineering, University of California, Berkeley, California 94720. Attention: L. M. Grossman and V. E. Schrock.

74. B. I. Spinrad, Oregon State University, Corvallis, Oregon 97331.

75. R. E. Schenter, Hanford Engineering Development Laboratory, P. 0. Box 1970, Richland, Washington 99352.

76. A. M. Perry, Institute for Energy Analysis, ORAU, Oak Ridge, Tennessee 378.30 .

77. M. R. Remley, Atomics International, 8900 Desoto Street, P. 0. Box 309, Canoga Park, California 91305.

78-79. Aerojet Nuclear Company, 550 Second Street, Idaho Falls, Idaho 83401. Attention: R. L. Heath and Y. D. Harker.

80. F. Rahn, Electri.c Power Research Institute, P. O. Box 10412, Palo Alto, California 94301.

81. K. Shure, Westinghouse Electric Corporation, Bettis Atomic Power Laboratory, P. 0. Box 79, West Mifflin, Pennsy.lvania 15122

82-387. Given distribution as shown in NRC categories 1 and 3 (25 copies - NTIS). 